Article

\title{
Quantitative Microbial Risk Analysis for Various Bacterial Exposure Scenarios Involving Greywater Reuse for Irrigation
}

\author{
Allison Busgang ${ }^{1}$, Eran Friedler ${ }^{2}$ (D), Yael Gilboa ${ }^{2}$ and Amit Gross ${ }^{1, *}$ \\ 1 Zuckerberg Institute for Water Research, Blaustein Institutes for Desert Research, \\ Ben Gurion University of the Negev, Sede Boqer Campus, Midreshet Ben Gurion 84990, Israel; \\ abusgang@gmail.com \\ 2 Faculty of Civil \& Environmental Engineering, Technion-Israel Institute of Technology, Haifa 3200003, \\ Israel; eranf@technion.ac.il (E.F.); ygilboa@technion.ac.il (Y.G.) \\ * Correspondence: amgross@bgu.ac.il; Tel.: +972-(0)8-6596-896
}

Received: 15 January 2018; Accepted: 28 March 2018; Published: 2 April 2018

\begin{abstract}
Greywater reuse can significantly reduce domestic water consumption. While the benefits are promising, risks are still under debate. Using a quantitative microbial risk-assessment model, we assessed the health risks associated with greywater reuse. The pathogens Salmonella enterica, Shigella spp., and Staphylococcus aureus were evaluated due to their possible prevalence in greywater and limited information regarding their potential risk with relation to greywater reuse for irrigation. Various exposure scenarios were investigated. Monte Carlo simulation was used and results were compared to the maximum "acceptable" limit of $10^{-6}$ disability-adjusted life years (DALY) set by the World Health Organization. Safe reuse was met for all worst-case exposure scenarios for Staphylococcus aureus, Salmonella enterica and Shigella spp. If their concentrations were kept below 10,000, 50 and $5 \mathrm{cfu} / 100 \mathrm{~mL}$, respectively. For the best-practice (more realistic) scenarios, safe reuse was met for Staphylococcus aureus if its concentration was kept below $10^{6} \mathrm{cfu} / 100 \mathrm{~mL}$. Salmonella enterica met the safe reuse requirements if a maximum concentration of $500 \mathrm{cfu} / 100$ $\mathrm{mL}$ was maintained and Shigella spp. if a maximum concentration was lower than $5 \mathrm{cfu} / 100 \mathrm{~mL}$. Based on reported concentrations of these bacteria in greywater, proper treatment and disinfection are recommended.
\end{abstract}

Keywords: greywater; QMRA; DALY; risk assessment; pathogen

\section{Introduction}

Greywater reuse has been suggested as an alternative to freshwater for some uses, particularly in water-scarce regions [1-4]. Greywater includes all domestic effluent, excluding the wastewater stream generated by toilets (blackwater). It is typically used on a single-household level to irrigate gardens, and can save up to $50 \%$ of individual household freshwater demand [1]. It should be noted that other usages of greywater have been suggested but were not discussed in the current study. However, along with its potential benefits, greywater must be handled responsibly to eliminate potential environmental and health risks. Raw greywater quality is highly variable, and it often contains pathogens (Table 1). Typically, a reduction in microbial counts is recorded after biological treatment of greywater, and a further reduction is observed after disinfection (Table 1). 
Table 1. Ranges of concentrations ( $\mathrm{cfu} / 100 \mathrm{~mL}$ ) of selected pathogens in raw, biologically treated, and disinfected greywater. Values in parentheses represents mean order of magnitude.

\begin{tabular}{|c|c|c|c|c|}
\hline Bacteria & Infection & Raw Greywater & $\begin{array}{c}\text { Biologically } \\
\text { Treated Greywater }\end{array}$ & $\begin{array}{l}\text { Disinfected } \\
\text { Greywater }\end{array}$ \\
\hline Staphylococcus aureus a & Skin infections & $10^{4}-10^{6}\left(10^{4}\right)$ & n.d. $-10^{3}(10)$ & n.d. $-10^{3}(<10)$ \\
\hline Shigella spp. & $\begin{array}{l}\text { Some species cause diarrhea, } \\
\text { inflammatory bacillary } \\
\text { dysentery, or shigellosis }\end{array}$ & n.d. ${ }^{b}$ & n.d. $-10^{4}$ (n.d.) ${ }^{\mathrm{c}}$ & n.d. \\
\hline Salmonella $^{d}$ enterica & $\begin{array}{c}\text { Some species cause } \\
\text { salmonellosis, bacteremia, } \\
\text { gastroenteritis, enteric fever }\end{array}$ & n.d. ${ }^{e}-10^{4}$ & n.d. $-10^{3}$ (n.d.) ${ }^{\mathrm{c}}$ & n.d. \\
\hline
\end{tabular}

Several studies focusing on Rotavirus, Norovirus, Campylobacter, and Cryptosporidium have defined the acceptable maximum levels of these pathogens and the pathogen-reduction requirements in wastewater and greywater [13,14]. These pathogens are all related to gastrointestinal diseases and are often used as model pathogens when investigating health risks in treated water, wastewater, and greywater. Other bacteria known to cause gastrointestinal diseases, such as Salmonella enterica, Shigella spp., and Staphylococcus aureus (the latter might also causes dermal infection), have also been found in greywater $[5,6,10,15]$. However, there are only a few limited quantitative studies in the literature on the risk of exposure to these pathogens in greywater [16-18].

Health risks associated with greywater reuse are largely unknown due to limited quantitative risk research [14,19-22]. Moreover, there are no reports connecting greywater reuse with actual public health issues such as disease outbreaks. These are likely to be the reasons for the wide discrepancy between countries' regulations for greywater reuse.

The main health concern associated with greywater reuse is mild to severe gastrointestinal diseases brought on by the possible ingestion of minute to significant amounts of greywater via various exposure pathways $[14,21,23]$. Quantitative microbial risk assessment (QMRA) is frequently used to define the human health risks of various practices involving wastewater reuse. It is comprised of four distinct steps: (i) hazard identification and enumeration of pathogens of concern; (ii) exposure assessment, which evaluates how and to what extent individuals might come into contact with the pathogens; (iii) dose-response modeling of the probability of illness based on the exposure to different dosages of pathogens; and (iv) risk characterization, to determine the annual probability of illness and, as a consequence, the maximum acceptable risk [24]. Overall, QMRA is used to determine the risks associated with specific exposure scenarios and to establish the required pathogen reduction in order to comply with (or be below) the maximum acceptable risk for a particular use. It is often used to create best-practice recommendations, guide law-makers, and inform policy [24].

The maximum acceptable risk is based on the World Health Organization's [25] standard measure of disability-adjusted life years (DALYs). The DALY is a measure of global disease burden expressed as the number of years lost due to illness, disability, or early death. The basic principle of this measure is to weigh each health outcome caused by a specific agent for its severity (between 0 and 1), with death being the most severe outcome (i.e., a value of 1 ). This weight is then multiplied by the duration of the health effect, and by the number of people in a population affected by the particular outcome. Summarizing all health outcomes caused by one agent will result in an estimate of the burden of disease attributable to this agent [26]. The WHO has set a maximum acceptable level of risk at $10^{-6}$ DALYs per person per year (PPPY) for all water-related illnesses [25]. Hence, [13] estimated that for a community, a maximum of $0.1 \%$ of the population may become ill each year.

The increasing practice of greywater reuse worldwide in recent years and the potential health risks involved, combined with a lack of significant risk evaluation, suggest the need for quantitative tools to evaluate health risks associated with greywater reuse. The focus of this research is the evaluation of quantitative microbial risk associated with the best-practice and worst-case scenarios 
of on-site greywater reuse for garden irrigation. Greywater due to its origin may contain skin- and mucous-tissue pathogens, such as Staphylococcus aureus [5]. Greywater originating from the kitchen sink and dishwasher may contain pathogens introduced by food handling such as Salmonella sp. and Shigella spp. Therefore, Salmonella enterica, Shigella spp., and Staphyloccocus aureus were identified as pathogens of concern for which risk assessment is of interest with respect to greywater reuse. Each bacterium was investigated individually for the maximum acceptable pathogen concentration that yields a risk below DALY limit for the examined scenarios.

\section{Materials and Methods}

\subsection{Development of the QMRA Model}

\subsubsection{Hazard Identification}

Salmonella enterica, Shigella spp., and Staphylococcus aureus were chosen as representative of the expected risks from greywater for this study. Salmonella enterica is a common pathogen associated with food handling in kitchen wastewater that might, on rare occasion, be included in greywater-reuse schemes. Shigella is an opportunistic pathogen that has been found in previous studies in treated greywater $[9,10,27]$. Salmonella enterica and Shigella spp. represent the oral route of ingestion and possible infection, which might result in symptoms of mild to severe gastroenteritis. Staphylococcus aureus is another common opportunistic pathogen found in greywater $[5,6,10]$ that can cause skin infections from dermal contact. It is shed during bathing activities and may enter the greywater stream through the bath and shower effluent $[6,10]$.

\subsubsection{Exposure Assessment}

The major exposure routes associated with greywater reuse for garden irrigation were identified as follows. The scenarios associated with the worst-case exposures were: (i) accidental drinking; (ii) garden irrigation that generate aerosols (e.g., sprinkler irrigation); (iii) garden work and lounging that might lead to hand-to-mouth contact with the greywater, such as after gardening, playing, or lounging in the irrigated area; (iv) food crop consumption of crops irrigated with greywater; and (v) accidental handwashing using the greywater. The best-practice exposure scenarios that one might be exposed to are modifications of the worst-case exposures to represent more realistic scenarios that consider practice guidelines, such as washing hands after being in the garden and avoiding the irrigation of vegetable gardens. Since in the best-practice exposure scenarios the residents are considered aware of the potential risks and professionals are the ones to maintain the greywater systems, scenarios such as of accidental drinking and garden irrigation were not analyzed. The scenarios associated with the best-practice exposures were (vi) system maintenance might lead to aerosols ingestion by the system technician; (vii) garden work and lounging might lead to hand-to-mouth contact when this scenario considers the reduction from handwashing; (viii) herb crop consumption considering reduction of microorganisms from washing herbs; and (ix) dermal contact during greywater system maintenance.

All parameters and detailed descriptions regarding the worst-case and best-practice exposure scenarios can be found in Table 2, with additional parameters found in Appendix A (Table A1). The approach taken was identification of exposure scenarios that are relevant for on-site greywater reuse (based on literature and the research team's long-term experience in a close monitoring of 20 greywater systems for over 8 years in 4 climatic zones in Israel [28]). The chosen volumes and frequencies are based on literature that dealt with such estimations (Table 2). From this literature, the ranges were stated, and a representative middle value was used. It should be noted that all values are estimations and not based on direct observation from on-site greywater systems. All of the parameters were assumed to follow a triangular distribution [29]. Exposure scenarios (i) through (iv); and (vi) through (viii) (Table 2), were investigated with respect to Salmonella enterica and Shigella spp. 
The scenarios investigated for Staphylococcus aureus were (v) and (ix), which are related to dermal contact with the greywater. Therefore, exposure scenarios associated with Staphylococcus aureus were not based on volume of water ingested but instead on the amount of time spent with one's hands submerged and the film thickness of the water remaining on the hands after washing while air drying [30]. All exposure scenarios were also associated with an estimated frequency of occurrence per year, because most of these activities can occur multiple times per year. Some of the scenarios' frequencies were taken from previous studies and others were collected in an epidemiological study that we performed, in which dozens of people were asked questions regarding their habits and possible contact with greywater on a weekly basis for a year, as detailed in [31]. Scenario (vii) (garden work and lounging) differs from scenario (iii) in that it includes the transfer efficiencies of microorganisms to various surfaces and hands. Scenarios (vii) and (ix) (dermal contact) additionally consider pathogen reduction from handwashing with soap after the exposure activity is completed (Table A1).

The scenarios of food and herb crop consumption (iv and viii) were represented by Equation (1), adapted from [14]:

$$
\mathrm{d}=\mathrm{IVc} 10^{-\mathrm{w}} \mathrm{e}^{-\mathrm{kt}}
$$

in which $d$ is the daily dose of bacteria that a person could be exposed to (cfu/day), $I$ is the average amount of produce consumed by the Israeli public per person per day (g/day), $V$ is the volume of water which might cling to the plant surface $(\mathrm{mL} / \mathrm{g}), c$ is the concentration of bacteria in the greywater $(\mathrm{cfu} / \mathrm{mL}), w$ is the $\log _{10}$ reduction in bacterial concentration from washing the produce, $k$ is the kinetic decay constant (per day), and $t$ is the withholding period (days). For the worst-case scenarios, it is assumed that no protective measures are taken with regard to irrigation practices. Thus, $w$ and $t$ in Equation (1) are considered to be zero. For the best-practice scenarios, it is assumed that the produce is washed and a withholding period is applied (Table A1). It should be noted that in this case, the food and herb crop consumption were calculated according to the Israeli data; however, it can easily be changed for each region around the word. 
Table 2. Potential worst-case and best-practice scenarios of exposure to greywater under investigation in this study. Additional relevant parameters associated with the best-practice exposure scenarios are found in Appendix A, Table A1.

\begin{tabular}{|c|c|c|c|c|c|c|}
\hline $\begin{array}{l}\text { Exposure } \\
\text { Scenario }\end{array}$ & Activity & Route of Exposure & Volume $(\mathrm{mL})^{a}$ & Frequency (PPPY) a,b & Comment & References \\
\hline $\mathrm{i}$ & Accidental drinking & $\begin{array}{l}\text { Accidental consumption of } \\
\text { greywater }\end{array}$ & $100(50-200)$ & $1(0.5-2)$ & $\begin{array}{l}\text { Child/third party unknowingly drinking from the garden } \\
\text { hose or system if exposed. }\end{array}$ & {$[20,32]$} \\
\hline ii & Garden irrigation & Aerosols from irrigation & $0.1(0.05-0.2)$ & $180(52-365)$ & $\begin{array}{l}\text { This scenario assumes that the residents are always present } \\
\text { in the garden during irrigation events and that aerosols } \\
\text { may be ingested during this time. }\end{array}$ & {$[20,31,32]$} \\
\hline iii & $\begin{array}{l}\text { Garden work and } \\
\text { lounging }\end{array}$ & $\begin{array}{l}\text { Ingestion due to contact } \\
\text { with plants, soil, pipes }\end{array}$ & $1(0.5-2)$ & $20(4-35)$ & Occurs by hand-to-mouth transfer of microorganisms. & {$[20,31,32]$} \\
\hline iv & $\begin{array}{l}\text { Food crop } \\
\text { consumption }\end{array}$ & $\begin{array}{l}\text { Ingestion of crops irrigated } \\
\text { with greywater }\end{array}$ & $\begin{array}{c}425(300-550) \mathrm{g} \\
0.1(0.05-0.2) \mathrm{mL}\end{array}$ & $7(0-14)$ & $\begin{array}{l}\text { This scenario examines the possibility of food crops } \\
\text { becoming contaminated with pathogens from direct } \\
\text { irrigation with greywater. }\end{array}$ & {$[17,20,31-33]$} \\
\hline $\mathrm{v}$ & Hand-washing & $\begin{array}{l}\text { Washing hands with } \\
\text { greywater }\end{array}$ & $\begin{array}{l}20(10-30) \mu \mathrm{m} \\
40(20-60) \mathrm{s}\end{array}$ & $1(0.5-2)$ & $\begin{array}{l}\text { Scenario associated with accidental dermal contact through } \\
\text { handwashing. Instead of volume, these values are film } \\
\text { thickness in } \mu \text { m of the water remaining after handwashing } \\
\text { (s represents washing time in seconds). }\end{array}$ & {$[34,35]$} \\
\hline vi & System maintenance & $\begin{array}{l}\text { Aerosols during system } \\
\text { maintenance }\end{array}$ & $0.1(0.05-0.2)$ & $4(3-6)$ & $\begin{array}{l}\text { This scenario assumes that the greywater system } \\
\text { technician is performing maintenance every } 2-4 \text { months. }\end{array}$ & [36] \\
\hline vii & $\begin{array}{l}\text { Garden work and } \\
\text { lounging }\end{array}$ & $\begin{array}{l}\text { Indirect ingestion } \\
\text { (contact with plants or soil) }\end{array}$ & $0.1(0.05-0.2)$ & $16(8-28)$ & $\begin{array}{l}\text { Occurs by hand-to-mouth transfer of microorganisms. } \\
\text { The transfer efficiencies of microorganisms to surfaces and } \\
\text { hands, and the reduction from handwashing is considered } \\
\text { in this scenario. }\end{array}$ & {$[20,37,38]$} \\
\hline viii & $\begin{array}{l}\text { Herb crop } \\
\text { consumption }\end{array}$ & $\begin{array}{l}\text { Ingestion of } \\
\text { greywater-irrigated herbs }\end{array}$ & $\begin{array}{c}5(0-20) \mathrm{g} \\
0.1(0.05-0.2) \mathrm{mL}\end{array}$ & $7(0-14)$ & $\begin{array}{l}\text { This scenario examines the possibility of herbs irrigated by } \\
\text { drip irrigation becoming contaminated with pathogens } \\
\text { from irrigation with greywater; environmental decay, } \\
\text { reduction from washing herbs, and a withholding period } \\
\text { are considered. }\end{array}$ & {$[14,17,20,39]$} \\
\hline ix & Dermal contact & $\begin{array}{l}\text { Hands contacting } \\
\text { greywater }\end{array}$ & $\begin{array}{l}20(10-30) \mu \mathrm{m} \\
40(20-60) \mathrm{s}\end{array}$ & $4(3-6)$ & $\begin{array}{l}\text { Accidental dermal contact during greywater system } \\
\text { maintenance. Instead of volume, these values are film } \\
\text { thickness in } \mu \text { m of the water remaining after handwashing } \\
\text { (s represents washing time in seconds). This scenario also } \\
\text { considers reduction from handwashing. }\end{array}$ & [34-37] \\
\hline
\end{tabular}

${ }^{a}$ The values of volume and frequency presented in the table are averages, and in parentheses are the minimum and maximum expected exposures that are $\pm 50 \%$ of the published average
value ${ }^{b}$ frequency is defined as the number of possible occurrences PPPY. Most exposure scenarios are likely to occur more than once a year. 


\subsubsection{Dose-Response Modeling}

The dose-response model is used to determine the risk of infection at various doses of exposure to the microorganism under investigation as described by [24]. Previous studies used the beta-Poisson dose-response model for Salmonella enterica [17,18,40,41] and Shigella spp. [24,42]:

$$
P_{\text {inf }}=1-\left(1+\frac{d}{N_{50}}\left(2^{\frac{1}{\alpha}}-1\right)\right)^{-\alpha}
$$

in which $P_{\text {inf }}$ is the probability of infection from a single exposure (based on $d$, the dose of microorganisms consumed (number of pathogens)), $N_{50}$ is the median infective dosage (number of pathogens), and $\alpha$ is a shape factor. The beta-Poisson dose-response model is widely used in QMRA studies, including risk assessment of greywater $[17,18,40,41]$.

Staphylococcus aureus follows an exponential dose-response model [30]:

$$
P_{\text {inf }}=1-\exp ^{(-d / k)}
$$

in which $d$ is the dose of microorganisms that a person may be exposed to, similar to the beta-Poisson model, with the units of days $\times$ number of pathogens per $\mathrm{cm}^{2}$, and $k$ is a characteristic of the process.

To account for multiple exposures per year, the individual probabilities are summed over a specified period of the year as follows:

$$
P=1-\left(1-P_{\text {inf }}\right)^{n}
$$

in which $P$ is the probability of infection from $n$ exposure events per year.

All parameters related to the model can be found in Table 3.

Table 3. Dose-response parameters for all bacteria under investigation.

\begin{tabular}{lcc}
\hline Parameter & Distribution or Point Estimates, Mean & References \\
\hline Disease burden (B) & DALYs per case of illness & \\
Salmonella spp. & $49 \times 10^{-3}$ & {$[43]$} \\
* Staphylococcus aureus & $2.6 \times 10^{-3}$ & {$[43]$} \\
Shigella spp. & $26 \times 10^{-3}$ & {$[44]$} \\
Dose-response models & & \\
Salmonella enterica & Beta-Poisson: $\alpha_{s e}=0.3136, N_{50 \text { se }}=2.4 \times 10^{4}$ & {$[17,18,40,41,45,46]$} \\
Staphylococcus aureus & Exponential: $\mathrm{k}_{\text {sa }}=1.31 \times 10^{7}$ & {$[30]$} \\
Shigella spp. & Beta-Poisson: $\alpha_{s}=0.162, N_{50 s}=1.127 \times 10^{3}$ & {$[24,42]$} \\
\hline * The value of disease burden for Staphylococcus aureus is a "composite" value which is based on major infection \\
pathways (and not distinctively for skin contact).
\end{tabular}

All exposure scenarios were simulated using Monte Carlo simulation. Each scenario ran 500,000 times, in which the frequency of volume and events were randomly changed according to the corresponding distribution, for each run. The pathogen concentrations were also modified between the limits appear in Table 1. The output of the model generated 500,000 pathogen concentrations compatible with annual probabilities of infection, for each scenario. The output data was statistically analyzed. The model was developed using Matlab, 2013.

\subsubsection{Risk Characterization}

The annual probability of infection was determined for each exposure scenario, and the risk was characterized as above or below the maximum tolerable risk suggested according to the DALY [25]. The DALY can be converted to a probability of illness or infection by the following equation:

$$
\mathrm{DALY}=P_{i l l} \times B \times S_{f}
$$


in which $P_{\text {ill }}$ is the probability of symptomatic illness occurring, $B$ is the pathogen-specific burden of disease, and $S_{f}$ is the susceptible fraction of the population. To keep the analysis more conservative, it was assumed that the probability of infection is equal to the probability of illness $\left(P_{\text {inf }}=P_{\text {ill }}\right)$. The entire population was also assumed to be susceptible to infection by all pathogens $\left(S_{f}=1\right)$; no immunity development was considered, and there was no reduction (die off) or increase (regrowth) in the concentration of pathogens present in the greywater between production (or treatment) and human contact. Using this equation, we calculated for each bacterium the maximum allowable probability of infection per person per year that was used as the maximum limit at which the risk is unacceptable.

\subsubsection{Uncertainty and Sensitivity Analyses}

To determine the reliability of the QMRA model predictions, uncertainty and sensitivity in the model input were determined following the method of [47]. In principle, the more uncertain a variable is, the higher the associated error may be, and the less sensitive the variable, the more stable it is to changes in the model.

The sensitivity analysis was performed for the examined pathogens and is demonstrated for the worst-case scenarios of Shigella spp. (Table A2). The analysis considers the ratios of the output results when the model was run using the 25th, 50th, and 75th percentiles of each input variable, respectively, while holding the remaining input variables at the 50th percentile.

A second sensitivity of the DALY was evaluated by running the model with changed burdens of disease within $+10 \%$ of the values in the literature.

\section{Results and Discussion}

\subsection{Risk Assessment}

The maximum acceptable probability of infection based on the limit of $10^{-6}$ DALYs PPPY of each bacterium under investigation was calculated according to Equation (5) and was in the range of $10^{-4}$ to $10^{-5}$. Each bacterium was investigated individually for the maximum acceptable pathogen concentration that yields a risk below this DALY limit for both the worst-case and best-practice scenarios described in Table 2.

The risk of infection from a specific pathogen is related to the actual dose received by a person and not to its concentration in the greywater (Equations (2) and (3)). It is therefore clear that different exposure scenarios will result in the reception of different quantities of bacteria; hence, the probability of infection will vary among scenarios. The results from exposure to Salmonella enterica in greywater showed that under all worst-case exposure scenarios, the risk was much higher than the DALY limit $\left(2.04 \times 10^{-5}\right.$ PPPY for Salmonella, Figure 1). Exposure scenarios of accidental drinking and garden work had the highest and lowest risk for Salmonella infection, respectively. Salmonella concentration of $50 \mathrm{cfu} / 100 \mathrm{~mL}$ resulted in crossing the threshold of the Salmonella DALY limit for the accidental drinking scenario, whereas for the garden work and lounging scenarios (iii and vii), the DALY limit was surpassed when Salmonella concentration was $500 \mathrm{cfu} / 100 \mathrm{~mL}$.

A few studies have reported the risks of Salmonella enterica in greywater [19,48]; however, the presence of this pathogen in greywater is questionable, because a thorough confirmation procedure is needed. Moreover, the major source of Salmonella enterica in households is food handling in the kitchen [49]; thus, it is thought to enter the greywater via the kitchen effluent [9]. The relatively low volume associated with kitchen effluent in comparison to other greywater sources, its high contamination with organic matter, and the potential presence of pathogens such as Salmonella enterica have led to recommendations by various researchers to exclude kitchen water from greywater-reuse schemes $[1,8,50,51]$. 


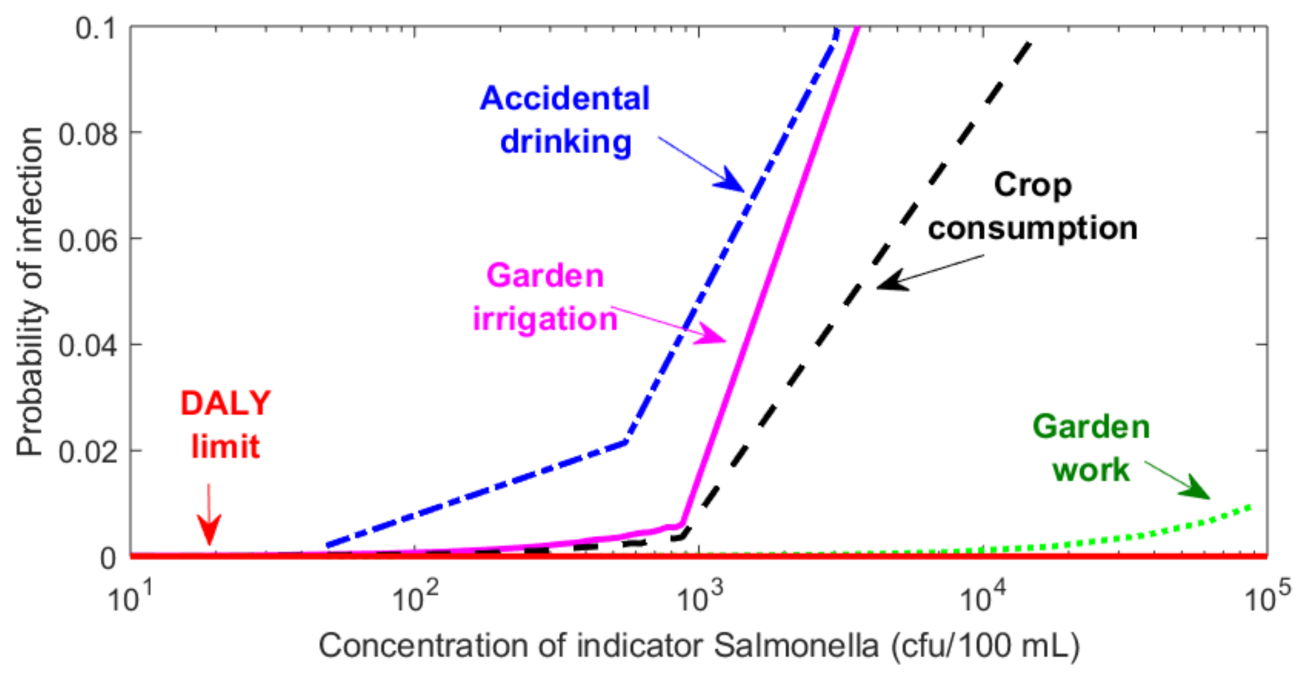

Figure 1. Probability of infection from Salmonella enterica in greywater under four worst-case exposure scenarios. The red solid horizontal line represents the DALY limit of acceptable risk as suggested by the WHO [25].

The potential exposure from hand-to-mouth contact during garden work and lounging demonstrates an acceptable risk up to a concentration of $500 \mathrm{cfu} / 100 \mathrm{~mL}$ (Table 4), whereas maximum acceptable risk associated with herb consumption and with the potential infrequent exposure to aerosols during system maintenance was estimated as $2 \times 10^{4} \mathrm{cfu} / 100 \mathrm{~mL}$.

Table 4. Best-practice scenarios for maximum tolerable concentration of the tested pathogens above which the DALY limits are compromised.

\begin{tabular}{ccccc}
\hline Bacteria & \multicolumn{2}{c}{ Maximum Tolerable Concentration in the Best-Practice Scenarios } \\
\hline & $\begin{array}{c}\text { Ingestion Due to } \\
\text { System } \\
\text { Maintenance }\end{array}$ & $\begin{array}{c}\text { Ingestion Due to } \\
\text { Garden Work and } \\
\text { Lounging }\end{array}$ & $\begin{array}{c}\text { Ingestion Due to } \\
\text { Herb Crop } \\
\text { Consumption }\end{array}$ & $\begin{array}{c}\text { Dermal } \\
\text { Contact }\end{array}$ \\
\hline Salmonella enterica $(\mathrm{cfu} / 100 \mathrm{~mL})$ & $2 \times 10^{4}$ & $5 \times 10^{2}$ & $2 \times 10^{4}$ & N.R. \\
\hline Shigella spp. $(\mathrm{cfu} / 100 \mathrm{~mL})$ & $<5$ & $<5$ & $<5$ & N.R. \\
\hline Staphylococcus aureus $(\mathrm{cfu} / 100 \mathrm{~mL})$ & N.R. & N.R. & N.R. & $5 \times 10^{6}$ \\
\hline $\begin{array}{l}\text { N.R.-not relevant, as } \text { S. aureus can be harmful via dermal contact whereas the others cannot (and S. aureus is not } \\
\text { harmful in other scenarios). }\end{array}$ & & &
\end{tabular}

Given the low quantities of Salmonella enterica typically found in biologically treated greywater, it does not represent a significant gastrointestinal risk (Table 1). Regardless, the maximum concentration of Salmonella enterica in greywater should not exceed $50 \mathrm{cfu} / 100 \mathrm{~mL}$. This can be achieved through biological treatment, preferably followed by disinfection.

A concentration of $5 \mathrm{cfu} / 100 \mathrm{~mL}$ was enough to cross the maximum acceptable probability of infection of Shigella spp. for the garden work scenario, while for the other scenarios the acceptable threshold was crossed at concentration below $1 \mathrm{cfu} / 100 \mathrm{~mL}$ (Figure 2). These results suggest that Shigella inactivation is required, and exposure to greywater should be minimized to prevent contact and ingestion of this microorganism. Yet, it is important to note that Shigella spp. has only been found in a few greywater samples [9]. 


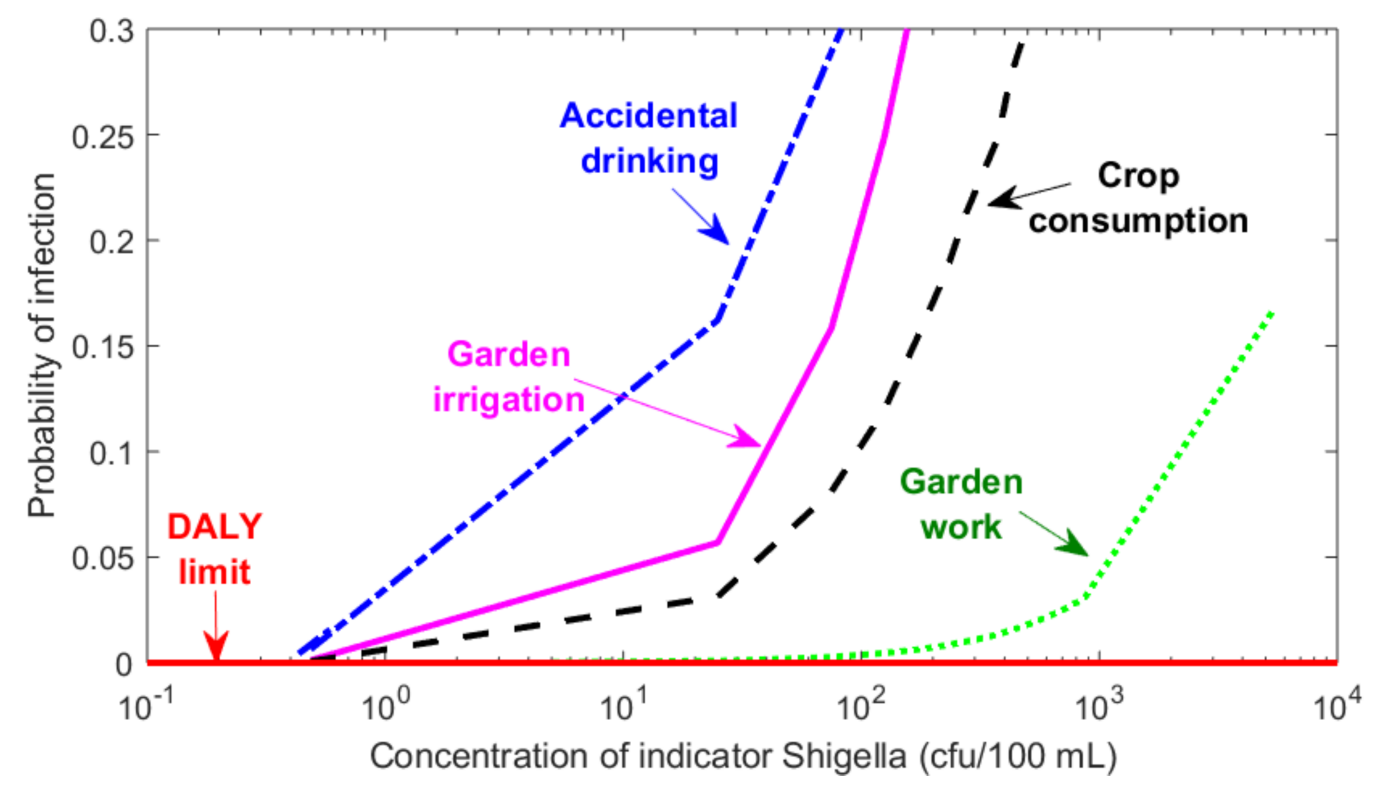

Figure 2. Probability of infection from Shigella spp. In greywater under four worst-case exposure scenarios (Table 2). The red solid horizontal line represents the DALY limit of acceptable risk as suggested by the WHO [25].

Similar to the results of the worst-case scenarios, concentration below $5 \mathrm{cfu} / 100 \mathrm{~mL}$ of Shigella spp. was found to produce acceptable risk in the best-practice scenarios (Table 4). The probabilities of infection were always above the DALY limit for all scenarios investigated, and the maximum acceptable concentration for all examined scenarios was $5 \mathrm{cfu} / 100 \mathrm{~mL}$. This supports the worst-case scenario results, which suggest that disinfection to non-detectable concentrations is required for safe reuse of greywater containing Shigella spp.

Chlorine tablets and low-pressure UV irradiation have been shown to be good disinfectants against all of the examined pathogens, with up to $8 \log$ reductions recorded [16,52-54]. Given that Salmonella enterica and Shigella spp. are found only rarely, at concentrations of up to 4 log gene copies $/ 100 \mathrm{~mL}$ (Table $1[1,17]$ ), the use of chlorine could reduce these bacteria to non-detectable levels [52].

The results from exposure to Staphylococcus aureus during handwashing (worst-case scenario) were found to be acceptable up to a concentration of $10^{6} \mathrm{cfu} / 100 \mathrm{~mL}$. This concentration is greater than that usually found in greywater (Figure 3).

The result of the best-practice exposure scenario for dermal contact during maintenance of the greywater treatment system was similar to that obtained from the worst-case scenario with acceptable risk of up to $10^{6} \mathrm{cfu} / 100 \mathrm{~mL}$ of Staphylococcus aureus (Table 4). The reason for the similar results between worst-case and best-practice scenarios stems from lower exposure frequency in the worst-case scenario than in the best-practice one. In other words, the worst-case scenario is considered a rare accident, whereas the best-practice exposure is expected to occur much more frequently.

In this study, it was determined that accidental drinking posed the highest risk to human health for all pathogens examined. 


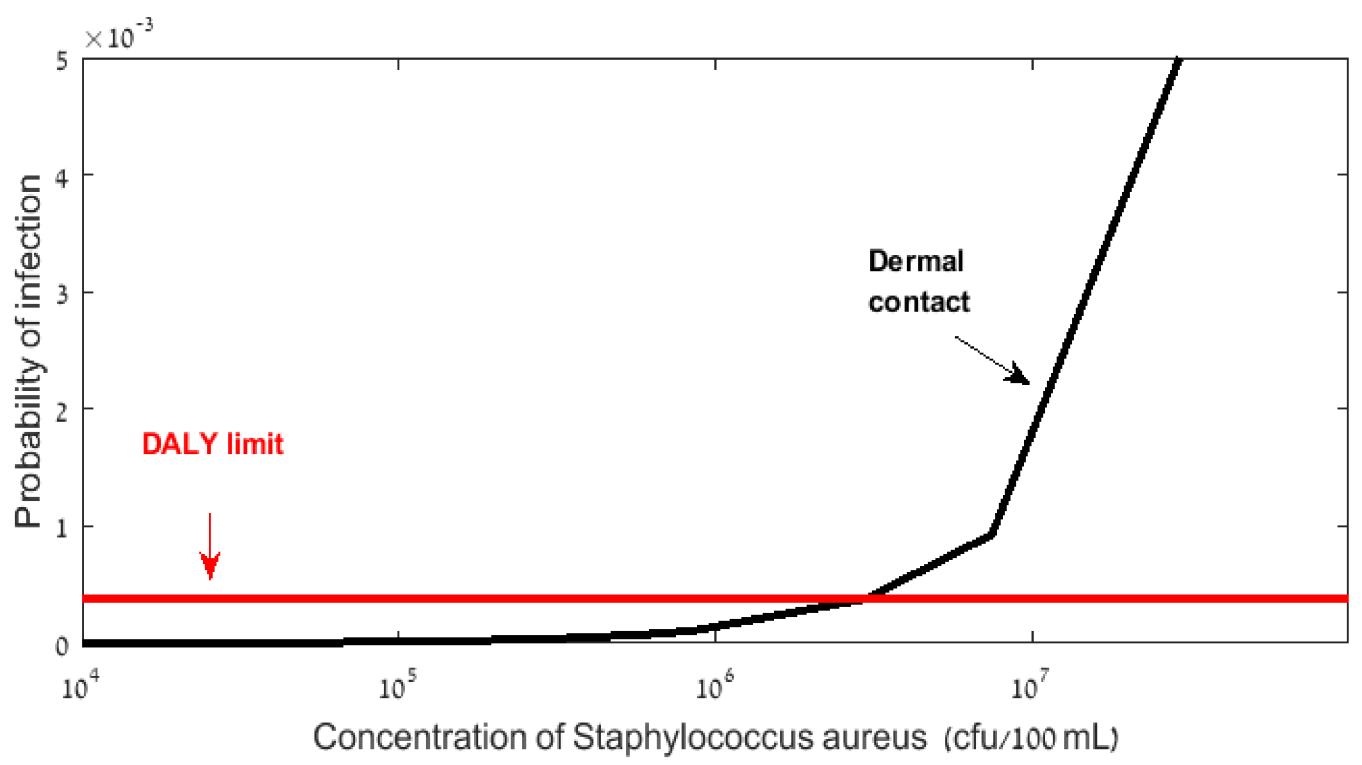

Figure 3. Probability of skin infection from worst-case exposure to Staphylococcus aureus due to accidentally washing hands in greywater. The red solid horizontal line represents the DALY limit of acceptable risk as suggested by the WHO [25].

\subsection{Uncertainty and Sensitivity Analyses}

Using Spearman's rank correlation, pathogen concentration was found to be the most uncertain variable (Figure 4). Spearman's rank correlation is used to determine the dependence of a result on a variable. A higher correlation suggests a higher dependence, and therefore importance in the uncertainty. This result suggests that pathogen concentration has the widest range in the model input data, and that more information on this variable is required.

Pathogen concentration was found to be the most important parameter in the sensitivity analysis (Table A2). This suggests that small changes in pathogen concentration will result in large changes in the output of the model, or in other words, in the probability of infection. Reducing the pathogen concentration is, consequently, the most effective way of reducing the risk of infection from greywater. Simple procedures, such as use of disinfectants (e.g., chlorine, UV light, etc.), drip and subsurface irrigation, and other physical barriers that prevent the spread of pathogens can be put in place to reduce potential risks associated with greywater reuse.

Few studies have considered the sensitivity of the DALY [55,56]. Nevertheless, the evidence suggests that it is a robust measure overall [56]. Variation in the disability weights for diseases that are both mild and frequent might lead to considerable effects on the calculated burden of disease, because the relative impact of a small difference (e.g., 0.1) is much larger at the mild end of the severity scale [55]. DALYs for mild and frequent diseases should be given special attention, and the uncertainty should be evaluated on a case-by-case basis.

The second sensitivity of the DALY indicated that the final result — the point at which the microbial concentration was deemed acceptable-was recorded, and the percent differences between each resulting concentration were determined. The differences in the end results were shown to vary between 9 and $12 \%$ (data not shown). This is not a significant variation, and it was therefore postulated that the DALYs used in this model are robust.

It is also important to recall that the model is highly conservative because of the assumptions that were made regarding the input variables, i.e., that the entire population is susceptible to infection by these pathogens and that every infection results in illness. We therefore postulate that QMRA can be used safely, despite the uncertainty in the DALYs. 


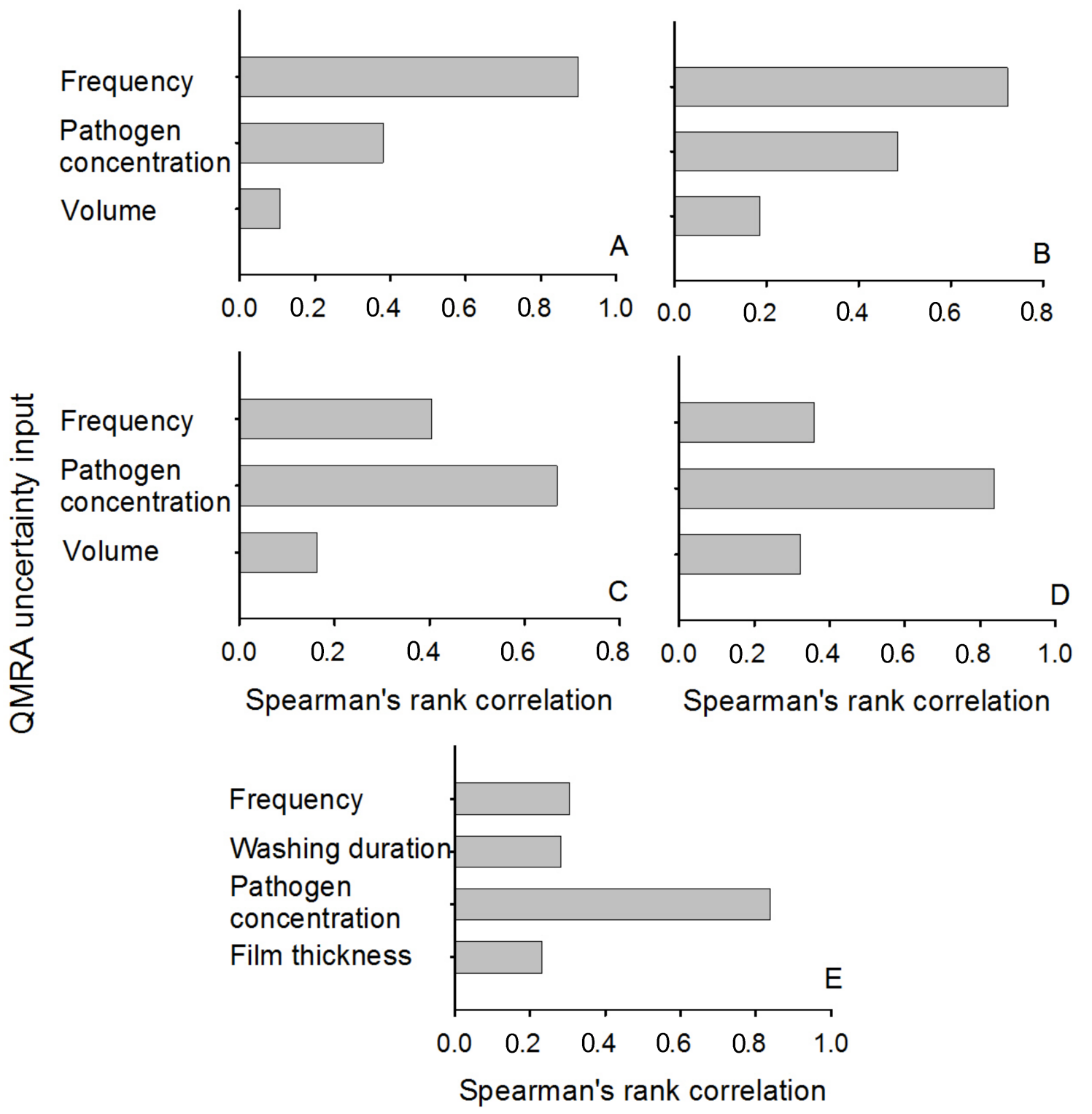

Figure 4. Uncertainty as determined by Spearman's rank correlation for each worst-case scenario using Shigella spp. as the representative bacteria. (A) Scenario (i)—accidental ingestion (drinking); (B) Scenario (ii)—aerosol exposure; (C) Scenario (iii)—garden work; (D) Scenario (iv)—crop consumption; and (E) Scenario (v)-handwashing.

\section{Conclusions}

Raw greywater, and often, biologically treated greywater, were shown to exceed the maximum level of acceptable risk at concentrations above $50 \mathrm{cfu} / 100 \mathrm{~mL}$ and $1 \mathrm{cfu} / 100 \mathrm{~mL}$ for Salmonella enterica and Shigella spp., respectively, under all worst-case exposure scenarios, excluding exposure to Staphylococcus aureus from handwashing $\left(10^{6} \mathrm{cfu} / 100 \mathrm{~mL}\right)$. Moreover, a good agreement between the results of the worst-case and best-practice exposure scenarios with respect to the maximum tolerable bacterial concentrations was found. It is therefore postulated that disinfection prior to reuse of greywater is recommended to meet the tolerable limit of risk.

Pathogen concentration was deemed the most important parameter in the model, suggesting that special effort should be made to minimize it in any reuse scheme. 
Acknowledgments: This research was funded by the Rosenzweig-Coopersmith Foundation (RCF) and Zuck Macabi Foundation. The authors would like to thank Karin Leeder and her research team at Monash University, Australia, for sharing information regarding DALYs.

Author Contributions: A.B. has written the matlab code and conducted most of the research as part of her MSc studies. A.G. and E.F. initiated and directed the study and the approach taken as the academic supervisors of Allison. They also supplied much of the relevant data for the model. Y.G. upgraded the matlab code and edited the final drafts. All co-authors contributed to completing and improving the text of the manuscript.

Conflicts of Interest: The authors declare no conflict of interest.

\section{Appendix}

Table A1. Additional relevant parameters associated with best-practice exposure scenarios.

\begin{tabular}{ccc}
\hline Additional Parameters Used in Exposure Assessment & Avg (Min-Max) & Reference \\
\hline Pathogen transfer efficiency to hands (\%) & $48(46-50)$ & [37] \\
\hline Pathogen transfer efficiency to surfaces (\%) & $55(51-60)$ & {$[37]$} \\
\hline Pathogen reduction from handwashing (\%) & $42(31-51)$ & {$[36]$} \\
\hline $\begin{array}{c}\text { Shigella reduction from handwashing (\%) } \\
\text { Pathogen reduction on produce from washing under a } \\
\text { continuous stream (log reduction) }\end{array}$ & $59(38-73)$ & {$[36]$} \\
\hline Withholding period (days) - uniform distribution & $(0.3-2.2)$ & {$[38]$} \\
\hline Decay rate (per day)—normal distribution & $(0.8107,0.3008)$ & {$[47]$} \\
\hline
\end{tabular}

Table A2. Sensitivity analysis inputs, outputs, and stepwise rank for each scenario.

\begin{tabular}{|c|c|c|c|c|c|c|c|c|}
\hline \multirow{2}{*}{$\begin{array}{l}\text { Exposure } \\
\text { Scenario }\end{array}$} & \multirow[t]{2}{*}{ Parameter } & \multicolumn{3}{|c|}{ Input Values } & \multicolumn{3}{|c|}{$\begin{array}{l}\text { Ratios of Output } \\
\text { Values }\end{array}$} & \multirow{2}{*}{$\begin{array}{l}\text { Stepwise } \\
\text { Rank }\end{array}$} \\
\hline & & p25 & p50 & p75 & p50:25 & p75:50 & p75:25 & \\
\hline \multirow{3}{*}{$\mathrm{i}$} & Volume $^{\mathrm{a}}$ & 93.61 & 113.91 & 139.64 & 1.22 & 1.23 & 1.49 & 2 \\
\hline & Pathogen concentration ${ }^{b}$ & 2.50 & 5.00 & 7.56 & 2.00 & 1.51 & 3.02 & 1 \\
\hline & Frequency & 0.93 & 1.13 & 1.39 & 1.21 & 1.22 & 1.48 & 3 \\
\hline \multirow{3}{*}{ ii } & Volume $^{\text {a }}$ & 0.93 & 1.13 & 1.39 & 1.22 & 1.23 & 1.49 & 3 \\
\hline & Pathogen concentration ${ }^{b}$ & 2.50 & 5.00 & 7.56 & 2.00 & 1.51 & 3.02 & 1 \\
\hline & Frequency & 15.11 & 19.74 & 24.23 & 1.31 & 1.23 & 1.60 & 2 \\
\hline \multirow{3}{*}{ iii } & Volume $^{\mathrm{a}}$ & 0.09 & 0.11 & 0.14 & 1.22 & 1.22 & 1.48 & 3 \\
\hline & Pathogen concentration ${ }^{b}$ & 2.50 & 5.00 & 7.56 & 2.00 & 1.51 & 3.02 & 1 \\
\hline & Frequency & 152.96 & 196.03 & 245.29 & 1.28 & 1.25 & 1.60 & 2 \\
\hline \multirow{3}{*}{ iv } & Volume $^{\mathrm{a}}$ & 9.39 & 11.36 & 13.85 & 1.21 & 1.22 & 1.48 & 3 \\
\hline & Pathogen concentration ${ }^{b}$ & 2.50 & 5.00 & 7.56 & 2.00 & 1.51 & 3.02 & 1 \\
\hline & Frequency & 152.23 & 196.17 & 245.99 & 1.29 & 1.25 & 1.62 & 2 \\
\hline \multirow{4}{*}{$\mathrm{v}$} & Film thickness ${ }^{c}$ & 0.0017 & 0.002 & 0.0023 & 0.63 & 1.17 & 0.74 & 2 \\
\hline & Pathogen concentration $^{b}$ & $2.50 \times 10^{5}$ & $4.99 \times 10^{5}$ & $7.51 \times 10^{5}$ & 0.63 & 2.02 & 1.28 & 1 \\
\hline & Duration $^{\mathrm{d}}$ & $3.94 \times 10^{-4}$ & $4.60 \times 10^{-4}$ & $5.27 \times 10^{-4}$ & 0.87 & 1.54 & 1.34 & 3 \\
\hline & Frequency ${ }^{a}$ & 0.93 & 1.35 & 1.39 & 1.07 & 1.38 & 1.48 & 4 \\
\hline
\end{tabular}

${ }^{\mathrm{a}}$ Volume in $\mathrm{mL} ;{ }^{\mathrm{b}}$ concentration in cfu $/ 100 \mathrm{~mL} ;{ }^{\mathrm{c}}$ film thickness in $\mu \mathrm{m} ;{ }^{\mathrm{d}}$ duration in seconds. 


\section{References}

1. Friedler, E. Quality of individual domestic greywater streams and its implication for on-site treatment and reuse possibilities. Environ. Technol. Lett. 2004, 25, 997-1008. [CrossRef] [PubMed]

2. Xue, X.; Schoen, M.E.; Ma, X.C.; Hawkins, T.R.; Ashbolt, N.J.; Cashdollar, J.; Garland, J. Critical insights for a sustainability framework to address integrated community water services: Technical metrics and approaches. Water Res. 2015, 77, 155-169. [CrossRef] [PubMed]

3. Jahne, M.A.; Schoen, M.E.; Garland, J.L.; Ashbolt, N.J. Simulation of enteric pathogen concentrations in locally-collected greywater and wastewater for microbial risk assessments. Microb. Risk Anal. 2017, 5, 44-52. [CrossRef]

4. Schoen, M.E.; Garland, J. Review of pathogen treatment reductions for onsite non-potable reuse of alternative source waters. Microb. Risk Anal. 2017, 5, 25-31. [CrossRef]

5. Gilboa, Y.; Friedler, E. UV disinfection of RBC-treated light greywater effluent: Kinetics, survival and regrowth of selected microorganisms. Water Res. 2008, 42, 1043-1050. [CrossRef] [PubMed]

6. Winward, G.P.; Avery, L.M.; Frazer-Williams, R.; Pidou, M.; Jeffrey, P.; Stephenson, T.; Jefferson, B. A study of the microbial quality of grey water and an evaluation of treatment technologies for reuse. Ecol. Eng. 2008, 32, 187-197. [CrossRef]

7. Friedler, E.; Yardeni, A.; Gilboa, Y.; Alfiya, Y. Disinfection of greywater effluent and regrowth potential of selected bacteria. Water Sci. Technol. 2011, 63, 931-940. [CrossRef] [PubMed]

8. Boyjoo, Y.; Pareek, V.; Ang, M. A review of greywater characteristics and treatment processes. Water Sci. Technol. 2013, 67, 1403-1424. [CrossRef] [PubMed]

9. Jefferson, B.; Palmer, A.; Jeffrey, P.; Stuetz, R.; Judd, S. Grey water characterisation and its impact on the selection and operation of technologies for urban reuse. Water Sci. Technol. 2004, 50, 157-164. [PubMed]

10. Benami, M.; Gross, A.; Herzberg, M.; Orlofsky, E.; Vonshak, A.; Gillor, O. Assessment of pathogenic bacteria in treated graywater and irrigated soils. Sci. Total Environ. 2013, 458-460, 298-302. [CrossRef] [PubMed]

11. Katukiza, A.Y.; Ronteltap, M.; Niwagaba, C.B.; Kansiime, F.; Lens, P.N.L. A two-step crushed lava rock filter unit for grey water treatment at household level in an urban slum. J. Environ. Manag. 2014, 133, $258-267$. [CrossRef] [PubMed]

12. Birks, R.; Hills, S. Characterisation of indicator organisms and pathogens in domestic greywater for recycling. Environ. Monit. Assess. 2007, 129, 61-69. [CrossRef] [PubMed]

13. Mara, D.D.; Sleigh, P.A.; Blumenthal, U.J.; Carr, R.M. Health risks in wastewater irrigation: Comparing estimates from quantitative microbial risk analyses and epidemiological studies. J. Water Health 2007, 5, 39-50. [CrossRef] [PubMed]

14. Barker, S.F.; O’Toole, J.; Sinclair, M.I.; Leder, K.; Malawaraarachchi, M.; Hamilton, A.J. A probabilistic model of norovirus disease burden associated with greywater irrigation of home-produced lettuce in Melbourne, Australia. Water Res. 2013, 47, 1421-1432. [CrossRef] [PubMed]

15. Kotut, K. Physico-chemical and microbial quality of greywater from various households in Homa Bay Town. Open Environ. Eng. J. 2011, 4, 162-169. [CrossRef]

16. Benami, M.; Gillor, O.; Gross, A. Potential microbial hazards from graywater reuse and associated matrices: A review. Water Res. 2016, 106, 183-195. [CrossRef] [PubMed]

17. Dalahmeh, S.S.; Lalander, C.; Pell, M.; Vinneras, B.; Jönsson, H. Quality of greywater treated in biochar filter and risk assessment of gastroenteritis due to household exposure during maintenance and irrigation. J. Appl. Microbiol. 2016, 121, 1427-1443. [CrossRef] [PubMed]

18. Schoen, M.E.; Ashbolt, N.J.; Jahne, M.A.; Garland, J. Risk-based enteric pathogen reduction targets for non-potable and direct potable use of roof runoff, stormwater, and greywater. Microb. Risk Anal. 2017, 5, 32-43. [CrossRef]

19. Diaper, C.; Dixon, A.; Butler, D.; Fewkes, A.; Parsons, S.A.; Strathern, M.; Stephenson, T.; Strutt, J. Small scale water recycling systems-Risk assessment and modelling. Water Sci. Technol. 2001, 43, 83-90. [PubMed]

20. Maimon, A.; Tal, A.; Friedler, E.; Gross, A. Safe on-site reuse of greywater for irrigation-A critical review of current guidelines. Environ. Sci. Technol. 2010, 44, 3213-3220. [CrossRef] [PubMed]

21. O'Toole, J.; Sinclair, M.; Malawaraarachchi, M.; Hamilton, A.; Barker, S.F.; Leder, K. Microbial quality assessment of household greywater. Water Res. 2012, 46, 4301-4313. [CrossRef] [PubMed] 
22. Blanky, M.; Sharaby, Y.; Rodríguez-Martínez, S.; Halpern, M.; Friedler, E. Greywater reuse-Assessment of the health risk induced by Legionella pneumophila. Water Res. 2017, 125, 410-417. [CrossRef] [PubMed]

23. Ottosson, J. Hygiene Aspects of Greywater and Greywater Reuse; Swedish Institute for Infectious Disease Control (SMI), Department of Water and Environmental Microbiology: Stockholm, Sweden, 2003.

24. Haas, C.N.; Rose, J.B.; Gerba, C.P.; Charles, P. Quantitative Microbial Risk Assessment; Wiley: New York, NY, USA, 1999.

25. WHO (World Health Organization). Guidelines for the Safe Use of Wastewater, Excreta and Greywater; WHO: Geneva, Switzerland, 2006.

26. Medema, G.; Ashbolt, N. QMRA: Its Value for Risk Management; WHO: Geneva, Switzerland, 2006; pp. 1-34.

27. Nganga, V.G.; Kariuki, F.W.; Kotut, K. A comparison of the physico-chemical and bacteriological quality of greywater from water deficient households in Homabay Town and Githurai Estates in Kenya. Open Environ. Eng. J. 2012, 5, 110-118. [CrossRef]

28. Alfiya, Y.; Gross, A.; Sklarz, M.; Friedler, E. Reliability of onsite greywater treatment systems in Mediterranean and arid environments-A case study. Water Sci. Technol. 2013, 67, 1389-1395. [CrossRef] [PubMed]

29. Wahlen, J.B. Microbial Risk Assessment of Graywater Reuse Using Quantitative Molecular Approaches for Estimating Pathogen Concentrations; North Carolina State University: Raleigh, NC, USA, 2013.

30. Rose, J.B.; Haas, C.N. A risk assessment framework for the evaluation of skin infections and the potential impact of antibacterial soap washing. Am. J. Infect. Control 1999, 27, S26-S33. [CrossRef]

31. Busgang, A.; Friedler, E.; Ovadia, O.; Gross, A. Epidemiological study for the assessment of health risks associated with graywater reuse for irrigation in arid regions. Sci. Total Environ. 2015, 538, 230-239. [CrossRef] [PubMed]

32. NRMMC, EPHC and AHMC (Natural Resource Management Ministerial Council, Environmental Protection and Heritage Council and Australian Health Ministers' Conference). National Water Quality Management Strategy: Australian Guidelines for Water Recycling: Managing Health and Environmental Risks (Phase 1); NRMMC: Canberra, Australia, 2006.

33. OECD (The Organization for Economic Co-operation and Development). Fruit and vegetable consumption among adults. In Health at a Glance: Europe 2012; OECD Publishing: Paris, France, 2012.

34. USEPA (US Environmental Protection Agency). Chapter 7-Dermal Exposure Factors. In Exposure Factors Handbook, 2011th ed.; National Center for Environmental Assessment, Office of Research and Development, U.S. Environmental Protection Agency: Washington, DC, USA, 2011; pp. 1-20.

35. WHO (World Health Organization). Guidelines on Hand Hygiene in Health Care: A Summary; WHO: Geneva, Switzerland, 2009.

36. Leggett, D.; Brown, R.; Stanfield, G.; Brewer, D.; Holliday, E. Rainwater and Greywater Use in Buildings: Decision-Making for Water Conservation; CIRIA: Westminster, UK; London, UK, 2001.

37. Curtis, V.; Cairncross, S. Effect of washing hands with soap on diarrhoea risk in the community: A systematic review. Lancet Infect. Dis. 2003, 3, 275-281. [CrossRef]

38. Jiang, X.; Dai, X.; Goldblatt, S.; Buescher, C.; Cusack, T.; Matson, D.; Pickering, L. Pathogen transmission in child care settings studied by using a cauliflower virus DNA as a surrogate marker. J. Infect. Dis. 1998, 177, 881-888. [CrossRef] [PubMed]

39. Amoah, P.; Drechsel, P.; Abaidoo, R.; Klutse, A. Effectiveness of common and improved sanitary washing methods in selected cities of West Africa for the reduction of coliform bacteria and helminth eggs on vegetables. Trop. Med. Int. Health 2007, 12, 40-50. [CrossRef] [PubMed]

40. Ottoson, J.; Stenstrom, T.A. Faecal contamination of greywater and associated microbial risks. Water Res. 2003, 37, 645-655. [CrossRef]

41. Schoen, M.E.; Xue, X.; Hawkins, T.R.; Ashbolt, N.J. Comparative human health risk analysis of coastal community water and waste service options. Environ. Sci. Technol. 2014, 48, 9728-9736. [CrossRef] [PubMed]

42. Crockett, C.; Haas, C.; Fazil, A.; Rose, J.; Gerba, C. Prevalence of shigellosis in the U.S.: Consistency with dose-response information. Int. J. Food Microbiol. 1996, 30, 87-99. [CrossRef]

43. Havelaar, A.H.; Haagsma, J.A.; Mangen, M.-J.J.; Kemmeren, J.M.; Verhoef, L.P.B.; Vijgen, S.M.C.; Wilson, M.; Friesema, I.H.M.; Kortbeek, L.M.; Van Duynhoven, Y.T.H.P.; et al. Disease burden of foodborne pathogens in The Netherlands, 2009. Int. J. Food Microbiol. 2012, 156, 231-238. [CrossRef] [PubMed] 
44. Van Lier, A.; McDonald, S.A.; Bouwknegt, M.; Kretzschmar, M.E.; Havelaar, A.H.; Mangen, M.J.J.; Wallinga, J.; de Melker, H.E. Disease burden of 32 infectious diseases in The Netherlands, 2007-2011. PLoS ONE 2016, 11. [CrossRef] [PubMed]

45. FAO/WHO. Hazard characterization of Salmonella spp. In broilers and eggs. In Joint FAO/WHO Expert Consultation on Risk Assessment of Microbiological Hazards in Foods; FAO: Rome, Italy, 2000; pp. 17-21.

46. Gale, P. Land application of treated sewage sludge: Quantifying pathogen risks from consumption of crops. J. Appl. Microbiol. 2005, 98, 380-396. [CrossRef] [PubMed]

47. Xue, J.; Zartarian, V.G.; Ozkaynak, H.; Dang, W.; Glen, G.; Smith, L.; Stallings, C. A probabilistic arsenic exposure assessment for children who contact chromated copper arsenate (CCA)-treated playsets and decks, Part 2: Sensitivity and uncertainty analyses. Risk Anal. 2006, 26, 533-541. [CrossRef] [PubMed]

48. Amha, Y.; Kumaraswamy, R.; Ahmad, F. A probabilistic QMRA of Salmonella in direct agricultural reuse of treated municipal wastewater. Water Sci. Technol. 2015, 71, 1203-1211. [CrossRef] [PubMed]

49. Cogan, T.A.; Bloomfield, S.F.; Humphrey, T.J. The effectiveness of hygiene procedures for prevention of cross-contamination from chicken carcases in the domestic kitchen. Lett. Appl. Microbiol. 1999, 29, 354-358. [CrossRef] [PubMed]

50. Christova-Boal, D.; Eden, R.; Mcfarlane, S. An investigation into greywater reuse for urban residential properties. Desalination 1996, 106, 391-397. [CrossRef]

51. Gross, A.; Azulai, N.; Oron, G.; Ronen, Z.; Arnold, M.; Nejidat, A. Environmental impact and health risks associated with greywater irrigation: A case study. Water Sci. Technol. 2005, 52, 161-169. [PubMed]

52. Rodda, N.; Bateman, B.; Kfir, R. Removal of Salmonella typhi, Shigella dysenteriae, Vibrio cholerae and Rotavirus from water using a water treatment tablet. Water Sci. Technol. 1993, 27, 347-350.

53. Friedler, E.; Gilboa, Y. Performance of UV disinfection and the microbial quality of greywater effluent along a reuse system for toilet flushing. Sci. Total Environ. 2010, 408, 2109-2117. [CrossRef] [PubMed]

54. Benami, M.; Gillor, O.; Gross, A. The question of pathogen quantification in disinfected graywater. Sci. Total Environ. 2015, 506-507, 496-504. [CrossRef] [PubMed]

55. Melse, J.M. A national burden of disease calculation: Dutch disability-adjusted life-years. Dutch Burden of Disease Group. Am. J. Public Health 2000, 90, 1241-1247. [PubMed]

56. Havelaar, A.H.; Melse, J.M. Quantifying Public Health Risk in the WHO Guidelines for Drinking-Water Quality: A Burden of Disease Approach; RIVM Report No. 734301022/2003; RIVM: Bilthoven, The Netherlands, 2003. 